\title{
Penyuluhan Manfaat Netiket pada Siswa-Siswi SMK Putra Mandiri Bangsa
}

\author{
Wandy Wandy ${ }^{1}$, Muhammad Agni Catur Bhakti ${ }^{1}$, Media Anugerah Ayu ${ }^{1}$, Teddy Mantoro ${ }^{1}$, \\ Muhamad Rausyan Fikri ${ }^{2}$ \\ 1. Prodi Ilmu Komputer, Fakultas Teknik dan Teknologi Universitas Sampoerna \\ 2. Prodi Sistem Informasi, Fakultas Teknik dan Teknologi Universitas Sampoerna \\ Email: wandy.wandy@sampoernauniversity.ac.id
}

\begin{abstract}
Abstrak
Populasi Indonesia yang besar menjadi pasar pengguna Telepon Seluler yang besar pula, di mana sebagian besarnya terkoneksi dengan Internet. Tipe perangkat yang terkoneksi dengan Internet kian beragam dengan harga yang juga kian terjangkau. Koneksi Internet yang cepat juga semakin terjangkau oleh pengguna. Ragam aplikasi untuk dapat berkomunikasi, bersosialisasi, dan berinteraksi semakin membentuk masyarakat pengguna yang semakin bergantung dengan teknologi ini. Diperlukan cukup edukasi kepada masyarakat untuk menggunakan teknologi ini dengan bijaksana, khususnya pada area beretika di Internet, mengingat konten yang tersebar dan terserap melalui Internet juga semakin cepat.
\end{abstract}

Kata Kunci: Netiket, Internet, Media Sosial, Pesan Instan, Pengabdian kepada Masyarakat

\begin{abstract}
Indonesian population is huge and it is becoming a huge market for mobile cellular phone, which most of them are connected to the Internet. The type and variety of those mobile phone devices are increasing with more affordable prices. Internet access is also getting faster and becoming more affordable. A variety of applications with the ability to communicate, socialize, and interact with people increasingly shape users to become more dependent to technology. It is needed to educate people to use this technology wisely, especifically in Internet manners, given that content that is spread and absorbed over Internet is also getting faster.
\end{abstract}

Keywords: Netiquette, Internet, Social Media, Instant Messaging, Community Service

\section{PENDAHULUAN}

Indonesia memiliki jumlah penduduk yang cukup besar. Tercatat oleh Biro Pusat Statistik pada tahun 2018, Indonesia memiliki populasi sebesar 265 juta jiwa [1]. Populasi masyarakat yang cukup besar ini menjadi pelanggan telepon seluler yang banyak pula, yaitu 320 juta pelanggan di tahun 2018 menurut Bank Dunia [8]. Tampak rasio 1:1,2 antara 1 orang warga Warga Negara Indonesia dan Pelanggan Seluler. Disebutkan juga pada oleh Bank Dunia, bahwa Indonesia memiliki populasi pengguna Internet sebesar 39,7\% di tahun 2018 [7], berarti sekitar 105 juta individu di Indonesia telah menggunakan Internet. 
Ponsel Pintar merupakan platform pengguna untuk dapat menginstalasi berbagai aplikasi, khususnya Surat Elektronik, Pesan Instan dan Media Sosial. Tetera pada DataReportal bahwa pengguna dewasa Ponsel Pintar di Indonesia tahun 2018 yakni 60\% dengan rata-rata kecepatan Internet 9.82 Mbps pada perangkat Seluler [2]. Kecepatan koneksi ini cukup untuk menjalankan berbagai aplikasi pada sebuah Ponsel Pintar secara pararel.

Disebutkan pula pada DataReportal, aplikasi WhatsApp Messenger, Facebook dan Instagram adalah 3 besar aplikasi Ponsel Pintar yang memiliki jumlah unduhan terbanyak dan memiliki pengguna aktif terbesar di Indonesia pada periode tahun 2018 [2]. Ketiganya merupakan aplikasi ponsel terbitan perusahaan yang sama dan merupakan aplikasi pesan instan dan media sosial.

Konten yang dikirimkan dan diterima pengguna berupa teks, gambar, suara dan video pada aplikasi ponsel dapat memperkaya konten saat berkomunikasi, berinteraksi dan bersosialisasi di Internet. Beretika dan beradab benar serta baik diperlukan saat aktivitas ini berlangsung sebagai warganet, hal ini dikenal dengan sebutan Netiket [3].

\subsection{NAMA KEGIATAN}

Aktivitas Pengabdian kepada Masyarakat ini mengangkat topik Netiket yang memiliki nama: Sesi Berbagi - Netiket.

\subsection{MAKSUD DAN TUJUAN}

Adapun maksud dan tujuan penyelenggaraan aktivitas Pengabdian kepada Masyarakat ini adalah:

1. Memberikan informasi elemen dasar komunikasi.

2. Mensosialisasikan definisi Netiket.

3. Menginformasikan sebaran pengguna Internet Indonesia.

4. Memperkenalkan profil pengguna Media Sosial Indonesia.

5. Melibatkan mahasiswa dalam aktivitas Pengabdian kepada Masyarakat di tingkat Program Studi.

6. Mengedukasi siswa-siswi sekolah untuk dapat memiliki etiket dan adab yang benar dan baik saat berkomunikasi, berinteraksi, dan bersosialisasi di Internet.

7. Memberikan pemahaman mengenai jejak digital. 
Jurnal Pelayanan dan Pengabdian Masyarakat (PAMAS)

\section{PELAKSANAAN KEGIATAN}

Pelaksanaan Pengabdian kepada Masyarakat ini berlangsung dan bertempat pada:

Hari/Tanggal: Sabtu, 16 November 2019

Waktu: $\quad$ 13:00 - 16:00 WIB

Tempat: $\quad$ SMK Putra Mandiri Bangsa, Kelurahan Cimande Hilir, Kabupaten Bogor

\section{PELAKSANAAN KEGIATAN}

\subsection{METODE KEGIATAN}

Berikut ini adalah metode kegiatan yang dilakukan:

- Ceramah Interaktif

Sesi ceramah interaktif berlangsung selama 20 menit oleh Dosen kepada siswasiswi dengan memberikan pemahaman mengenai elemen dasar komunikasi, Netiket, sebaran pengguna Internet dan Sosial Media di Indonesia, bagaimana beretika pada Sosial Media dan Pesan Instan, dan Jejak Digital. Ceramah menampilkan presentasi menggunakan aplikasi Microsoft PowerPoint menggunakan laptop dan proyektor, konten disajikan berupa teks dan pemutaran video dengan perangkat pengeras suara portabel.

- Tanya-Jawab

Sesi tanya-jawab berlangsung antara siswa-siswi dengan Dosen secara langsung. Siswa-siswi diberikan kesempatan bertanya dengan maksimum 5 buah pertanyaan. Buah tangan diberikan kepada siswa-siswi yang berinisiatif bertanya sebagai wujud apresiasi.

- Diskusi dan Presentasi

Siswa-siswi di tiap kelas dibagi menjadi 5 orang dalam satu kelompok dan diminta untuk berdiskusi mengenai topik Netiket. Siswa-siswi disediakan kertas karton dan spidol untuk menuangkan hasil pemikiran dan kemudian hasil diskusi dipresentasikan di depan kelas menggunakan flipchart.

- Penutupan dan Sesi Foto Bersama

Usai seluruh sesi berakhir, Dosen, Mahasiswa dan Guru sekolah mengevaluasi singkat aktivitas ini dalam kurun waktu 30 menit, kemudian agenda ditutup dengan sesi photo bersama Dosen, Mahasiswa, Guru dan Siswa-Siswi di lapangan sekolah. 
Jurnal Pelayanan dan Pengabdian Masyarakat (PAMAS)

\subsection{PARTISIPAN}

Aktivitas Pengabdian kepada Masyrakat kali ini memiliki jumlah partisipan sekitar 135 orang dengan sebaran sebagai berikut:

- Dosen, 5 orang.

- Mahasiswa, sekitar 30 orang.

- Siswa-Siswi, berkisar 100 orang.

Keseluruhan partisipan terdisribusi pada 4 ruang kelas di lantai 2 SMK Putra Mandiri Bangsa.

\subsection{LUARAN}

Adapun luaran dari aktivitas Pengabdian kepada Masyarakat ini adalah peningkatan pengetahuan siswa-siswi mengenai etika di Internet secara benar dan baik untuk dapat segera diterapkan di kehidupan sehari-hari.

\section{HASIL PELAKSANAAN DAN EVALUASI}

\subsection{HASIL PELAKSANAAN}

Berikut adalah hasil pelaksanaan yang mengacu pada Maksud dan Tujuan kegiatan Pengabdian kepada Masyarakat kali ini:

\begin{tabular}{llr}
\hline$\#$ & \multicolumn{1}{c}{ Maksud dan Tujuan } & Keterangan \\
\hline 1. & Memberikan informasi elemen dasar komunikasi. & Terealisasi \\
2. & Mensosialisasikan definisi Netiket. & Terealisasi \\
3. & Menginformasikan sebaran pengguna Internet Indonesia. & Terealisasi \\
4. & Mengenalkan profil pengguna Media Sosial Indonesia. & Terealisasi \\
5. & Melibatkan mahasiswa dalam aktivitas Pengabdian kepada Masyarakat & Terealisasi \\
& di tingkat Program Studi. & \\
6. & Mengedukasi siswa-siswi sekolah untuk dapat memiliki etiket dan adab & Terealisasi \\
& yang benar dan baik saat berkomunikasi, berinteraksi, dan bersosialisasi \\
& di Internet. & \\
7. Memberikan pemahaman mengenai jejak digital. & Terealisasi
\end{tabular}

\subsection{EVALUASI}

\section{Faktor Pendukung}

Di bawah ini adalah sejumlah faktor pendukung yang diidentifikasi selama kegiatan berlangsung: 
- Partisipan telah familiar dalam menggunakan teknologi telepon seluler beserta aplikasi media sosial dan pesan instan.

- Ketersediaan jumlah laptop dan proyektor yang mencukupi dalam mendukung presentasi kegiatan.

- Keterlibatan banyak mahasiswa dalam mengorganisir adik-adik siswa-siswi sebelum, saat dan usai acara dirasakan sangat membantu kegiatan penyuluhan berlangsung.

\section{Faktor Penghambat}

Sebaliknya, faktor penghambat yang dirasakan terjadi saat aktivitas berjalan adalah:

- Kuantitas koordinasi Dosen sebagai penyampai materi dan rekan-rekan Mahasiswa yang lebih dahulu mempersiapkan peralatan dan perlengkapan di kelas dirasakan perlu untuk ditingkatkan.

- Jumlah pengeras suara dan kabel HDMI yang kurang memadai untuk menjangkau seluruh partisipan siswa-siswi di 3 ruang kelas.

- Durasi penyelenggaraan kegiatan dirasakan kurang dan perlu untuk diperpanjang, khususnya untuk segmen bertanya-jawab dan berdiskusi, guna memberikan kesempatan pada siswa-siswi untuk lebih dapat menyampaikan pendapat yang berkaitan dengan Netiket.

\section{DOKUMENTASI}

Berikut ini adalah sejumlah dokumentasi kegiatan: 

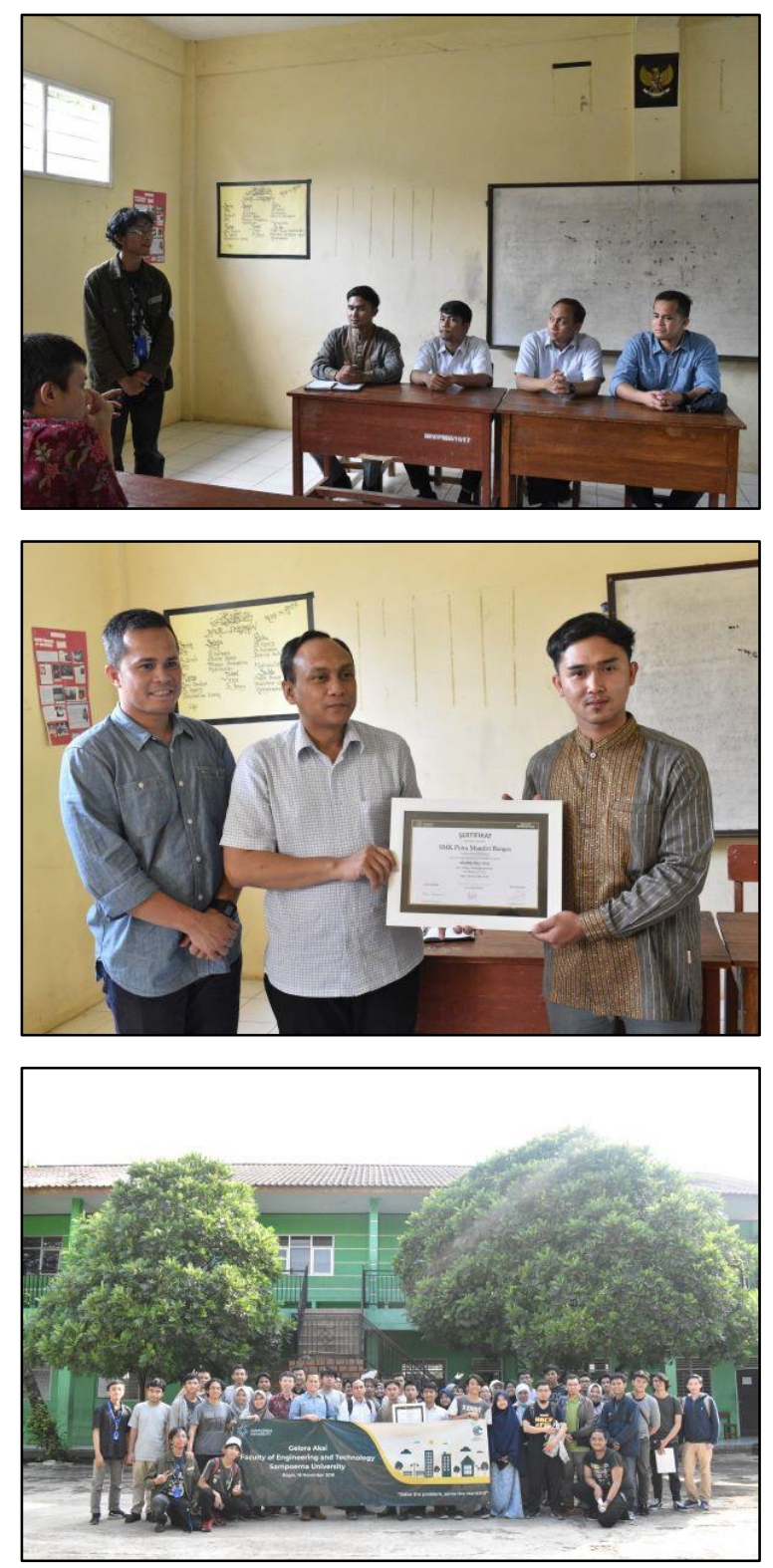

\section{SIMPULAN}

\subsection{KESIMPULAN}

1. Pada kegiatan kali ini, Kami telah memberikan informasi mengenai elemen dasar komunikasi, sebaran pengguna dan profil pengguna Internet di Indonesia, serta arti penting dan manfaat Netiket dalam kehidupan sehar-hari.

2. Kegiatan Pengabdian kepada Masyarakat ini berupaya mengedukasi siswa-siswi sekolah untuk dapat memiliki etiket dan adab yang benar dan baik saat berkomunikasi, berinteraksi, dan bersosialisasi yang melibatkan sejumlah rekanrekan mahasiswa. 
3. Setiap orang seyogyanya berkomunikasi dengan baik pada aplikasi yang terkoneksi dengan Internet.

4. Perlu dipahami bahwa berkomunikasi pada kanal Internet memiliki dampak negatif bila dijalankan dengan cara yang kurang baik dan/atau kurang sopan.

\section{DAFTAR PUSTAKA}

Biro Pusat Statistik. 2019. Statistical Yearbook of Indonesia.

DataReportal. 2018. Digital 2018: Indonesia di https://datareportal.com/reports/digital2018-indonesia?rq=digital\%20indonesia (akses Februari 2020).

Fahrimual, Yuhdi. 2018. Netiquette: Etika Jejaring Sosial Generasi Milenial dalam Media Sosial. Jurnal Penelitian Pers dan Komunikasi Pembangunan. 22(1): 69-78.

Fakultas IImu Administrasi Universitas Indonesia. Etika Menghubungi Melalui Telepon Genggam di https://fia.ui.ac.id/etika-menghubungi-dosen-melalui-telepongenggam/ (akses Februari 2020).

Limbong, Tonni. 2018. Etika Dunia Maya. Semiloka Undang-Undang Informasi dan Transaksi Elektronik (UU-ITE) dan Etika Komunikasi dalam Dunia Maya. 1-12.

Nur Hadi W. 2006. Etika Berkomunikasi di Dunia Maya dengan Netiquette. Seminar Nasional Matematika dan Pendidikan Matematika. 341-362.

World Bank, The. Individuals using the Internet (\% of population) - Indonesia di https://data.worldbank.org/indicator/IT.NET.USER.ZS?locations=ID (akses Februari 2020).

World Bank, The. Mobile cellular subscriptions - Indonesia di https://data.worldbank.org/indicator/IT.CEL.SETS?locations=ID lakses Februari 2020). 